diseases from teenager to adult: Amsterdam Growth and Health Study. Prev Med 1990;19:642-55.

38 Kuh DJL, Cooper C. Physical activity at 36 years: patterns and childhood predictors in a longitudinal study. Epidemiology and Community Health 1992;46:114-19.

39 Kelder SK, Perry CL, Klepp KI, Lyttle LI. Longitudinal tracking of adolescent smoking, physical activity and food choice behaviors. Am $\mathcal{Y}$ Public Health 1994;84:1121-6.

40 Andersen LB, Haraldsdottir J. Tracking of cardiovascular disease risk factors including maximum oxygen uptake and physical activity from late teenage to adulthood: an 8-year follow-up study. 7 Intern Med 1993;234:309-15.

41 Sallis JF, Berry CC, Broyles SL, McKenzie TL, Nader PR. Variability and tracking of physical activity over $2 \mathrm{yr}$ in Voung children. Med Sci Sports Exerc 1995;27:1042-9.

42 Andersen LB. Changes in physical activity are reflected in changes in fitness during late adolescence. 7 Sports Med Phys Fitness 1994;34:390-7.

43 Glenmark B, Hedberg G, Jansson E. Prediction of physical activity level in adulthood by physical characteristics, physical performance and physical activity in adolescence: an 11-year follow-up study. Eur f Appl Physiol 1994;69: an $11-$-yea.

44 Ilmarinen J, Rutenfranz J. Longitudinal studies of the changes in habitual physical activity of schoolchildren and working adolescents. In: Berg K, Eriksson BO, eds. Children and exercise. Baltimore: University Park Press, 1980:14959.

45 Trudeau F, Shephard RJ. Long-term effect of primary school physical education on sedentarity of the adult. Med Sci Sports Exerc. In press

\section{George Nightingale}

George Nightingale was educated at Campbell College and Queen's University, Belfast. He joined the RAF Medical Branch in May 1943 , seeing service in the Middle East and the Persian Gulf. He resumed his surgical career at Belfast City Hospital from 1946 to 1949. For the next 10 years he worked in the Cameroons and Sierra Leone. Surgery started very early to avoid the heat of the day and was of necessity very varied. One list, for example, included a cataract, a hysterectomy, a dental extraction, and a hernia.

In 1960 he moved to Shepton Mallet and joined the general practice at nearby Oakhill, where he remained until his reluctant retirement on his 70th birthday in 1985 . He is remembered in Oakhill for visiting snowed in patients by tractor in a bad winter, and for many local events at which he did duty, including the Royal Bath and West Show.

He was a supporter of the British Limbless Exservicemen, and was made an Honorary Member of their organisation. He had a long interest in sports medicine, and was delighted when his son, Danny, was one of the gold medal winners in the modern pentathlon at the Montreal Olympics in 1976. Although his final illness was short, he had made an excellent recovery from heart attacks and extensive chest surgery about 15 years earlier.

His interests outside medicine included classical music, and he was an accomplished pianist. He enjoyed the restoration of his ancient cottage at North Wootton where he had an immaculate garden decorated with ammonite fossils, and a weed-free lawn. Although not noted for his tolerance of fools gladly or otherwise, George was a generous and entertaining companion. $\mathrm{He}$ died aged 78 and leaves a wife, Joan, four sons, a daughter, and 10 grandchildren.

A L WALBY

45 Derryvolgie Avenue Belfast BT9 6FP 